\title{
PSOCID TAXOCENOSES STRUCTURE AND DIVERSITY (INSECTA: PSOCOPTERA) IN THE FOREST ECOSYSTEMS OF THE PICEETI-FAGETA S. LAT.ZONE IN THE WESTERN CARPATHIAN MTS.
}

\author{
O. Holuša
}

Received: May 2, 2011

\begin{abstract}
HOLUŠA, O.: Psocid taxocenoses structure and diversity (Insecta: Psocoptera) in the forest ecosystems of the Piceetifageta s. lat. zone in the Western Carpathian Mts. Acta univ. agric. et silvic. Mendel. Brun., 2011, LIX, No. 5, pp. 95-104

Psocid taxocenoses (Psocoptera) were studied in forest ecosystems of the Western Carpathian Mts. during 1997-2001. As a study frame, vegetation tiers (= altitudinal vegetation zones) were used. Lower units of forest typological system (forest type complexes) were used for a classification of ecological conditions as well. Only a part of material, i.e. individuals that was found in the forest ecosystems of Piceeti-fageta s. lat. communities ( $=$ the $6^{\text {th }}$ spruce-beech vegetation tier) was evaluated for purpose of this work. This vegetation tier is widespread in higher parts of mountains (the Moravskoslezské Beskydy Mts. and partly in the Oravské Beskydy Mts.). 554 adults comprising 17 species were found in total in the $6^{\text {th }}$ vegetation tier. As eudominant species, the following ones were found: Caecilius despaxi, Caecilius burmeisteri, Mesopsocus unipunctatus, and Stenopsocus lachlani; as dominant species, the following ones were found: Caecilius flavidus and Reuterella helvimacula. In natural geobiocenoses with the level of naturalness of 1 or 2, the following species were found: as eudominant species: Mesopsocus unipunctatus, Stenopsocus lachlani, Caecilius despaxi, Amphigerontia bifasciata and Reuterella helvimacula. Dominant species was Caecilius burmeisteri and Caecilius flavidus. Taxocenoses of psocids were evaluated by Detrended Correspondence analysis (DCA) and Divisive Cluster analysis (DvClA). This material was compared to another material gained from various vegetation tiers in the Western Carpathians Mts. The characteristic species composition of psocids in the $6^{\text {th }}$ vegetation tier was as follows - Cecilius despaxi-Stenopsocus lachlani-Mesopsocus unipunctatus - Reuterella helvimacula.
\end{abstract}

Psocoptera, taxocenoses, diversity, forest ecosystems, vegetation tier - Piceeti-fageta s. lat., Moravskoslezské Beskydy Mts., Western Carpathian Mts

A complex psocopterological research was initiated recently in a territory of the Czech Republic and Slovakia in 1997. The aim of the systematic study of psocids conducted in the Western Carpathian Mts. was to define the species diversity and characteristic species composition of psocids in particular vegetation tiers (= altitudinal vegetation zone, further only vegetation tier) and to prove an applicability of vegetation zones or lower units of geobiocenological or forest-typological systems in zoocenological studies.

Only faunistic data are mostly known from the Czech Republic from 20 th century (cf. HolušA, 2003a, 2008). However, Holuša (2001, 2003a, 2003b, $2007 \mathrm{~b}, \mathrm{c})$ studied an ecological problem of psocid taxocenoses composition dependence on vegetation tiers in the Moravskoslezské Beskydy Mts., in the Podbeskydská pahorkatina hills (HoLušA, 2005) and in the alluvium of the Odra river (the Protected 
landscape area of Poodří) (HoLušA, 2007a). Moreover, MÜCKSTEIN \& HoLUŠA (2003) studied the composition of psocid taxocenoses in different ecosystem types and its dependence on naturalness level of forest ecosystems in the region of the Ždárské vrchy hills.

Knowledge about the composition of psocid taxocenoses in vegetation tiers (or "lower" units i.e. Forest type complexes) in Western Carpathians Mts. from the $7^{\text {th }}$ (Fageti-piceeta s. lat.) and the $8^{\text {th }}$ (Piceeta s. lat.) vegetation tiers were published by HoLušA (2007c), and also from the $5^{\text {th }}$ vegetation tier (Abietifageta s. lat.) by HoLušA (2009).

The aim of presented article is to analyse composition and diversity of psocid taxocenoses of the $6^{\text {th }}$ vegetation tier (Piceeti-fageta s. lat.) i.e. and to discuss the differences with other known vegetation tiers i.e. the $5^{\text {th }}$ (Abieti-fageta s. lat.), the $7^{\text {th }}$ (Fagetipiceeta s. lat.) and the $8^{\text {th }}$ (Piceeta s. lat.) vegetation tiers.

\section{METHODS}

The net of equally distributed geobiocenological research plots was situated in regions of eastern Moravia, eastern Silesia and northern Slovakia in the territory of Polonic and Westcarpathian biogeographical subprovinces (i.e. in the region of the Western Carpathian Mts). Plots were selected in all vegetation tiers occurring in this region, i.e. from the $3^{\text {rd }}$ (communities of Querci-fageta s. lat.) to the $9^{\text {th }}$ (communities of Pineta mugi s. lat.) (cf HolušA, 2003a). Plots were placed in such parts of forest stands which represent a particular vegetation tier and in which it was possible to collect a representative material of psocids. Approximately the same number of permanent plots was placed in all vegetation tiers. Permanent plots were marked out in the best-preserved parts of nature reserves (with the level of naturalness 1 or 2 according to ElLenberg $(1973,1978)$ and additional plots were selected in modified parts of nature reserves or in managed forests with the level of naturalness 3 or 4 according to ELLENBERG $(1973,1978)$.

The material was obtained from permanent sampling sites during the vegetation period (from the beginning of May to the middle of September). The samples were collected by sweeping with a sweep net of $50 \mathrm{~cm}$ mouth in diameter. Branches of trees and bushes were beaten with the same sweep net in the extent of about $1 \mathrm{~m}$ from the branch end and up to approximately $2.5 \mathrm{~m}$ height. Individual collection of adults also complemented this method. During sweeping and beating, 30 sweepings or beatings were carried out in each locality. Caught psocids were sucked into an exhauster and stored in a small test tube with $70 \%$ alcohol. All samples were collected and identified by the author. The evidence material is deposited in 70\% alcohol in the author's collection. Papers of GÜNTHER (1974) and LIENHARD (1998) were used for identification; nomenclature, zoogeographical distribution and ecological demands were used according to LIENHARD (1977, 1998).
Samples were sorted into vectors "habitats of psocids", where the following factors were taken into account: biogeographical region, ecological conditions (according to the forest type complexes) and tree or shrub species, from which the material was obtained (samples were also distinguished according to the capture method; captured either in a herb layer or by the Malaise trap). For example: BE6Ssm, where BE denotes the biogeographical region of the Beskydy Mts. (No. 3.10, cf. CuleK, 1996), 6S represent forest type complexes 6S (i.e. PiceetoFagetum mesotroficum, in material were not evaluated communities with codes $6 \mathrm{O}, 6 \mathrm{P}$ and $6 \mathrm{R}$, because they are azonal communities) and $s m$ is an acronym for the tree species Picea abies.

Diversity was evaluated by Shannon-Wiener $\left(\mathrm{H}_{\mathrm{s}}\right)$ and Brilouin diversity index $\left(\mathrm{H}_{\mathrm{B}}\right)$. Both indexes, Shannon-Wiener and Brilouin, were computed according to KAESLER \& MuLVANy (1976a, b). Diversity indexes of individual habitats were calculated from a total number of captured specimens (Table I). Some material was excluded from statistical processing because of a small number of collected specimens in some plots (i.e. species in a lower number than 5 specimens or 2 species even less than 3 specimens) to prevent a data distortion.

\section{Detrended Correspondence Analysis - DCA}

Detrended Correspondence Analysis (DCA), according to GAUCH (1982), Hill (1974) and HiLl \& GAUCH (1980), proceeds from the method of Principal Component Analysis (PCA), used for non-linear data. Axes were adjusted in order to prevent criteria deformation by the axis ends in the DCA-analysis. The unit length of axes corresponds with the average species dispersion. In different parts of axis

I: Values of Indexes of diversity and equitability for particular "habitats of psocids" in the vegetation tier of Piceeti-fageti s. lat.

\begin{tabular}{lcccccc}
\hline \multirow{2}{*}{ biotope } & \multirow{2}{*}{ Nsp } & \multirow{2}{*}{$\mathbf{N}$} & \multicolumn{4}{c}{$\mathbf{N}_{\mathbf{c}}$} \\
\cline { 6 - 8 } & & & $\mathbf{H}_{\mathbf{s}}$ & $\mathbf{E}_{\mathbf{S}}$ & $\mathbf{H}_{\mathbf{B}}$ & $\mathbf{E}_{\mathbf{B}}$ \\
\hline BE6Bbk & 2 & 6 & 0.299 & 0.598 & 0.451 & 0.650 \\
BE6Fbk & 5 & 26 & 0.584 & 0.427 & 0.746 & 0.463 \\
BE6Fsm & 8 & 40 & 1.603 & 0.890 & 1.858 & 0.893 \\
BE6Sbk & 6 & 41 & 1.064 & 0.673 & 1.223 & 0.683 \\
BE6Sjd & 4 & 40 & 0.944 & 0.757 & 1.069 & 0.771 \\
BE6Spod & 2 & 5 & 0.461 & 1.000 & 0.673 & 0.971 \\
BE6Ssm & 6 & 362 & 1.467 & 0.836 & 1.500 & 0.837 \\
BE6Zsm & 4 & 14 & 0.786 & 0.721 & 1.029 & 0.742 \\
OR6Bbk & 3 & 7 & 0.534 & 0.699 & 0.796 & 0.725 \\
OR6Bjd & 5 & 13 & 1.038 & 0.854 & 1.378 & 0.856 \\
OR6Bsm & 6 & 22 & 1.127 & 0.771 & 1.400 & 0.782 \\
\hline
\end{tabular}

Nsp - number of species

$\mathrm{N}$ - number of specimens

$\mathrm{H}_{\mathrm{S}}$ - Shannon-Wiener index of diversity

$\mathrm{E}_{\mathrm{S}}$ - Equatibility

$\mathrm{H}_{B}-$ Brillouin index of diversity

$\mathrm{E}_{\mathrm{B}}$ - Equatibility 


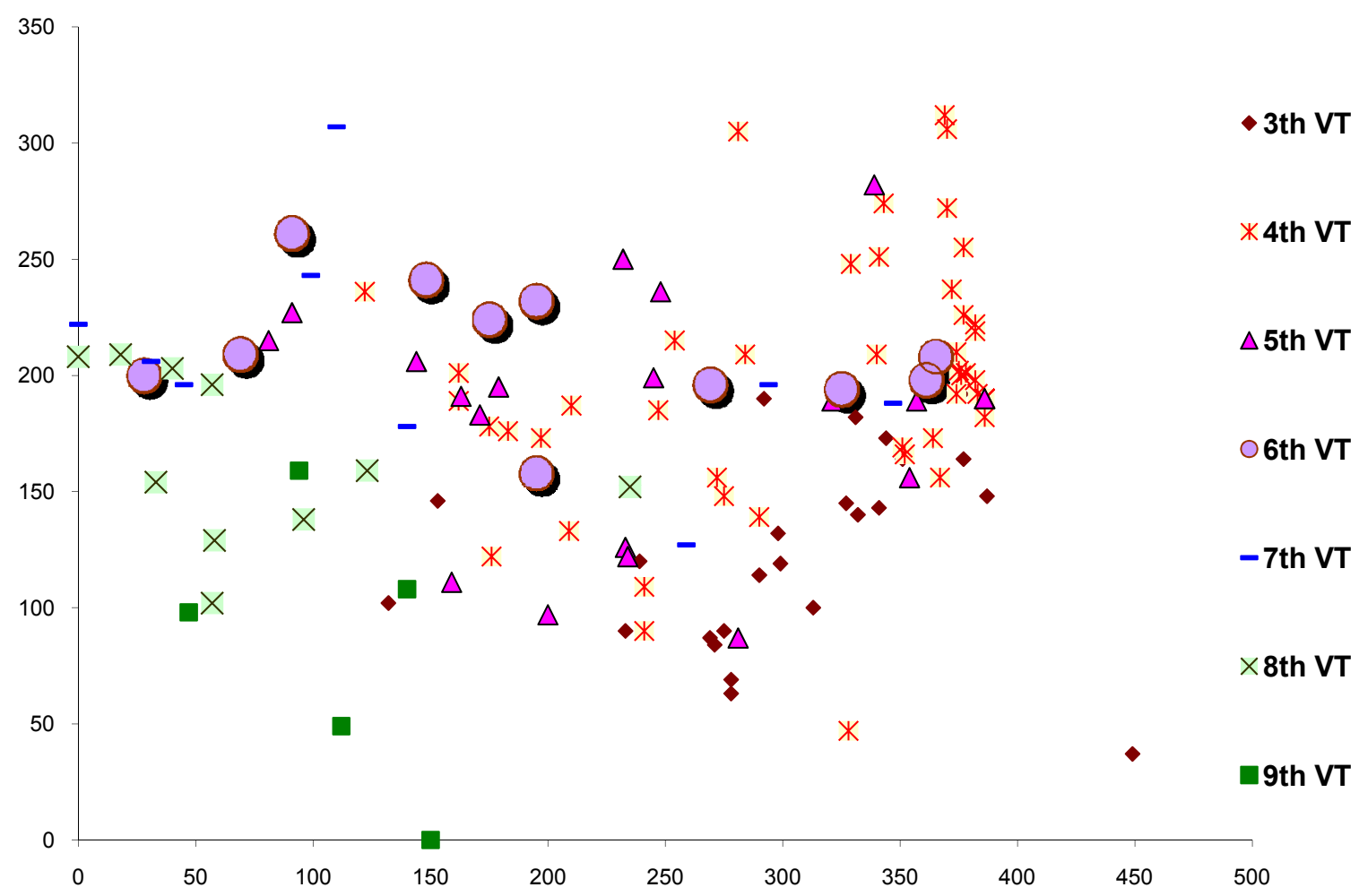

1: DCA analysis of psocid biotopes with marked biotopes of Piceeti-fageta ( $6^{\text {th }}$ vegetation tier) tier (axis $x$ - gradient of vegetation tiers, axis q- gradient of hydricity)

it remains unchanged. The DCA ordination method has a quite heuristic character. Interpretation of axes and ordination positions of particular species is based on their ecology with a view to habitat characteristics. Modified SW Decorana was used to process the DCA analysis, which was adapted for zoocenological data processing (Povolný \& ZnoJIL, 1990).

\section{Divisive Cluster Analysis - DvClA}

Divisive Cluster Analysis (DvClA) represents a method of hierarchic divisive classification (GOWER, 1967, ORLócI, 1975). The ordination of groups is performed twice by "Reciprocal averaging" (RA). All vectors are projected into the main axis as a super-ellipsoid. In the second phase, partial complexes of vectors are divided according to species ordinate in particular vectors and according to abundance of particular species (indicators) as well. These indicators are automatically selected by the program in compliance with the species spectrum of particular vectors (habitats) for the end parts of ordination axis. Used modification 'Twinspan algorithm' comes from a gradual division of habitats and species. Every processed file is ordinated by RA method, whereupon characteristic species (or biotopes) are associated with axes ends. Central parts of axes are ordinated consequently. On the base of gained results, it is searched for species combinations, which are characteristic of parts of ordination axes and can be used as appropriate "tools for cuts" (HıLL, 1974). This method was modified for the purpose of this study, because the first version was defined for phytocenological studies only. Column heads represent abbreviations of biotopes. Numbers in columns below indicate the division of appropriate algorithm (every habitat is divided, marked 0 or 1). There are species names in the left column and on the right there is one algorithm division of species spectrums in groups. The main field represents the semiquantitative relative frequency of particular species in groups corresponding with their biotopes. Explanations: - species does not occur, 1 - rare species, 2 - very scarce, 3 - scarce, 4 - common, 5 - very common to subdominant, 6 - dominant. Groups of psocid species and groups of habitats were organized to increase their clearness so that there is an evident species transfer within biotopes in the diagonal direction from the left upper corner to the right lower corner.

Acronyms of trees and shrubs (investigated tree species): sm - Picea abies, bk - Fagus sylvatica, jd - Abies alba, pod - copse.

\section{The characteristic of the $6^{\text {th }}$ vegetation tier (Piceeti-fageta s. lat.)}

According to HolušA \& HolušA (2010) $6^{\text {th }}$ Vegetation tier (Piceeti-fageta s. lat.) represents geobiocenoses where Fagus sylvatica is a dominant 


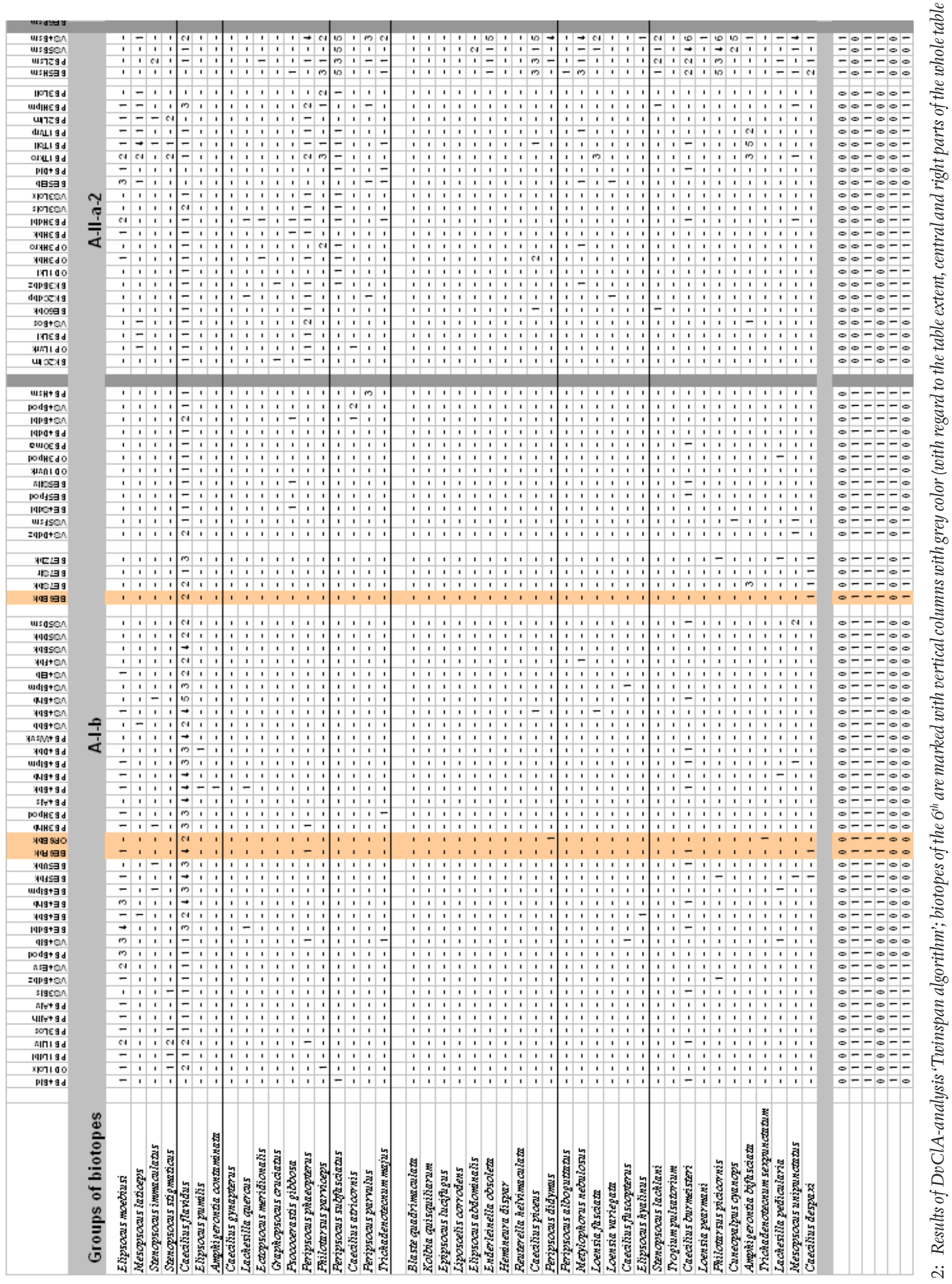




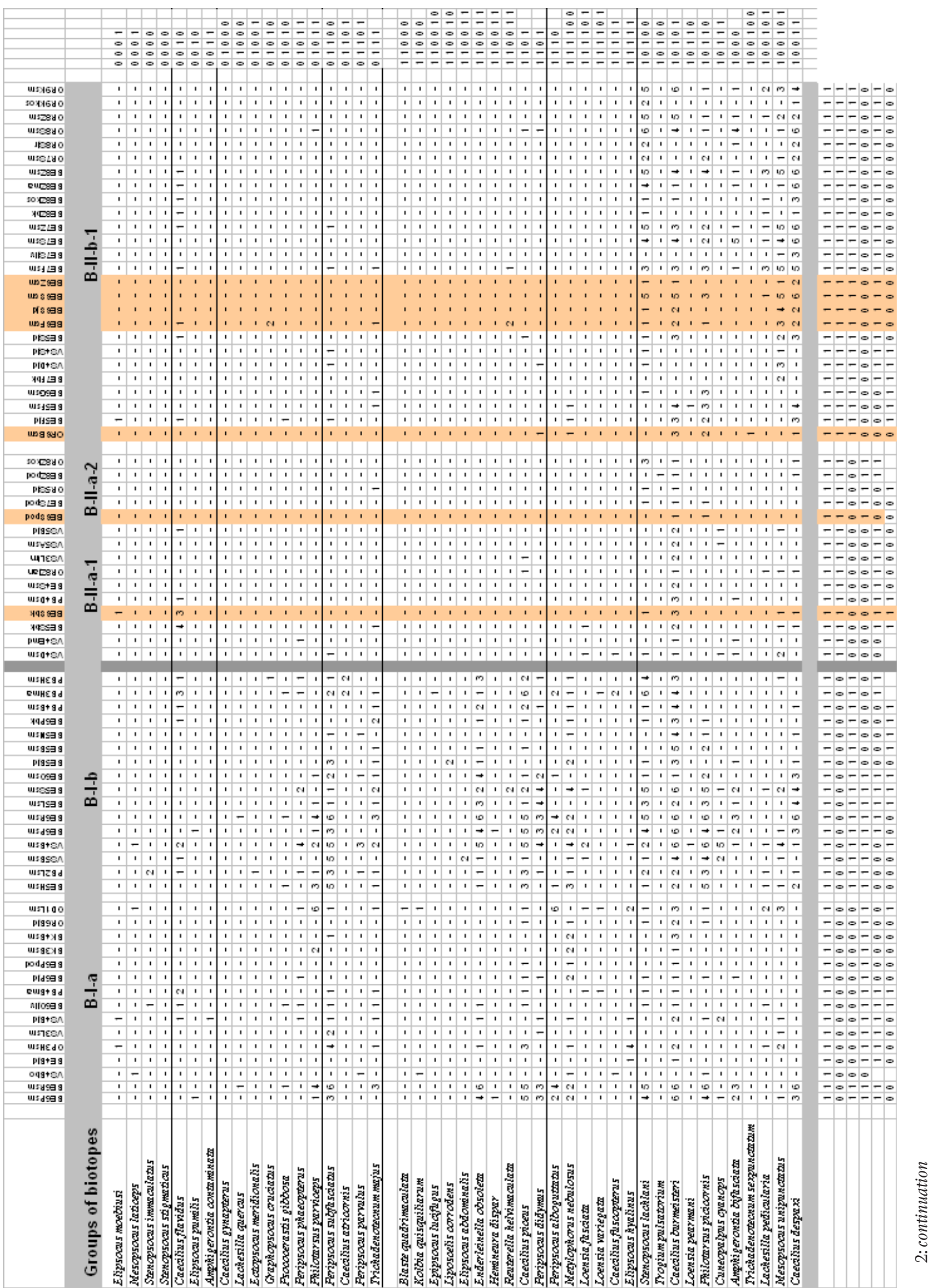


species in natural conditions, it creates the main level of stands (the maximum height of cca 32 $33 \mathrm{~m})$. Fagus sylvatica create also the overtopped tree filling. Abies alba and Picea abies significantly take part in tree species composition. Abies alba reaches in the height structure to the main and co-dominant level with the height up to $40 \mathrm{~m}$ (maximum measured height was $36 \mathrm{~m}$ ) and its representation in natural geobiocenoses is up to $30 \%$. Picea abies, which has its optimum in the $6^{\text {th }}$ vegetation tier, reaches the co-dominant level and then the highest heights (with potential maximum $60 \mathrm{~m}$, present maximum measured height was $45 \mathrm{~m})$. Acer pseudoplatanus, which occurs only as additional tree species, reaches only the overtopped level. Taxus bacchata and Sorbus aucuparia occur individually in the overtopped level. the $6^{\text {th }}$ vegetation tier occupies higher parts of mountains, in places with altitude from $860 \mathrm{~m}$ a.s.l. to $1100 \mathrm{~m}$ a.s.l. with the centre of occurrence in the interval of 920-940 $\mathrm{m}$ a.s.l. Soils arose on the flysh series of rocks of sandstones and shales, insular on the deluvial loams. There are represented the following soil types: cambisols (subtypes typical, individually pseudogleyic), podzols (typical, humic), also cryptopodzols occur there (typical, ranker), partially rankers. $6^{\text {th }}$ vegetation tier occurs in a relatively higher scale only in the Natural forest area (further only NFA) 40, only individually in the NFA 41 or in the Oravské Beskydy Mts. in Slovakia (on the base of authors investigations). It occupies $1.1 \%$ of the study area. It has, in contrast to $5^{\text {th }}$ vegetation tier (cf. HoLuŠA, 2003a, 2009), significantly lower representation. There are the following most widespread communities (units according to the system of PLíva, 1971, 1991): Forest type complex (further only FTC) 6S (Piceeto-Fagetum mesotrophicum), FTC 6F (Piceeto-Fagetum fastigiosum lapidosum mesotrophicum)) and FTC 6B (Piceeto-Fagetum eutrophicum).

\section{RESULTS AND DISCUSSION}

554 adults comprising 17 species were found in total. Out of that, the following eudominant species were found: Caecilius despaxi, Caecilius burmeisteri, Mesopsocus unipunctatus, and Stenopsocus lachlani; and as dominant species, the following ones were found: Caecilius flavidus and Reuterella helvimacula. In natural geobiocenoses with the level of naturalness of 1 or 2 , the following eudominant species were found: Mesopsocus unipunctatus, Stenopsocus lachlani, Caecilius despaxi, Amphigerontia bifasciata and Reuterella helvimacula. Dominant species were Caecilius burmeisteri and Caecilius flavidus. Resulting from the comparison of the tree colonization, all tree species - i.e. Picea abies, Abies alba and Fagus sylvatica, were inhabited by approximately the same species number (5 or 6 species), however with distinct differences between abundances on particular tree species. The most numerous taxocenosis was found at Picea abies. Abies alba and Fagus sylvatica were colonised by psocids in lower abundances (see Table I).

The DCA-analysis might be interpreted as follows: the $x$-axis denotes an influence of vegetation tiers and the $q$-axis refers to an influence of hydricity (cf. HolUŠA, 2007c).

These factors might increase a presumption of mutual correlation, nevertheless all vegetation tiers include habitats with a high hydricity - flooded habitats, water logging and peaty habitats as well as dry or desiccating habitats. As every vegetation tier comprehends a large scale of habitats - from dry to peaty habitats, the hydricity of habitat does not correlate with the altitude within the collected material. Habitats of $6^{\text {th }}$ vegetation tier creates the elongated elliptical dotted field along the $x$-axis. The dotted file of the $6^{\text {th }}$ vegetation tier in comparison with the $5^{\text {th }}$ vegetation tier is slightly left sided, however the $6^{\text {th }}$ vegetation tier along the $q$-axis is at same place as the field of the $5^{\text {th }}$ vegetation tier but it is narrower. It can be assumed, that the dotted field of the $6^{\text {th }}$ vegetation tier is more compact as far as the factor of hydricity is concerned. There is not a dispersion as with the $5^{\text {th }}$ vegetation tier and lower vegetation tiers. The shape of the dotted field is in compliance with the geobiocenological character of the ecosystems of the $6^{\text {th }}$ vegetation tier which has a more balanced hydricity conditions and it is the vegetation tier with a higher representation of Picea abies. The biotopes of the $6^{\text {th }}$ vegetation tier are sorted in the DvClA-analysis into several groups of biotopes, likewise at other vegetation tiers there is an influence of tree species. The biotopes with Fagus sylvatica are placed into the A-I-b group with biotopes of the zonal $3^{\text {rd }}-5^{\text {th }}$ vegetation tiers of broad-leaved tree species. The biotopes with coniferous species (Picea abies and Abies alba) are placed in the B-II-a group and also in the B-II-b-I group. The last group is created by the biotopes of higher vegetation tiers - i.e. $5^{\text {th }}-9^{\text {th }}$ vegetation tiers.

There were found higher values of diversity indexes in the $6 \mathrm{~F}$ communities for the BE6Fsm psocid biotope, i.e. $H_{S} 1.60$ and $H_{B} 1.86$, a high value was also found for the BE6Ssm psocid biotope i.e. $\mathrm{N}_{30}-\mathrm{H}_{\mathrm{S}} 1.31$ and $\mathrm{H}_{\mathrm{B}} 1.58$ (see Table I). The highest values of diversity are related to Picea abies, which is very convenient for psocids as it was proved by the species and abundance inhabitancy. Generally speaking, the indexes of diversity $\mathrm{H}_{\mathrm{s}}$ are in the interval of $0.30-1.60$ and the $\mathrm{H}_{\mathrm{B}}$ indexes are in the interval of $0.45-1.86$.

The characteristic species combination of psocids for the 6th vegetation tier was established as follows: Caecilius despaxi - Stenopsocus lachlani - Mesopsocus unipunctatus - Reuterella helvimacula. Caecilius despaxi which is clearly more dominant, in contrast to the $5^{\text {th }}$ vegetation tier. And also Reuterella helvimacula is more dominant. Peripsocus subfasciatus, P. phaeopterus and Metylophorus nebulosus are missing in this vegetation tier, in contrast to lower vegetation tiers. The occurrence of "spruce" corticolous and folicolous species is typical of this vegetation tier, 
in contrast to the characteristic species combination of the $5^{\text {th }}$ vegetation tier which was identified as follows: Caecilius flavidus - C.burmeisteri - C.despaxi Metylophorus nebulosus - Philotarsus picicornis. There is a conspicuous change of characteristic psocid species, however also in the dominance of Caecilius despaxi diagnostic species which occurs in the $6^{\text {th }}$ vegetation tier as a eudominant species.

In conclusion, the data is based on relatively small sample of the material, and should take in account the short-term of study (two growing seasons), so the findings may have limited explanatory power. We can assume the influence of fluctuations, which can be removed by long-term monitoring or permanent monitoring of the composition taxocenoses. However, the results are the first data on the composition of taxocenoses of model group i.e. psocids (Psocoptera) in the zone of Piceeti-fageta s. lat.

\section{CONCLUSION}

The results of this work with previous results for the $5^{\text {th }}, 7^{\text {th }}$ and $8^{\text {th }}$ vegetation tiers create a survey of compositions of psocid taxocenoses in the higher vegetation tiers, i.e. of $5^{\text {th }}$ Abieto-fageta s. lat., $6^{\text {th }}$
Piceeti-fageta s. lat., $7^{\text {th }}$ Fageti-piceeta s. lat and $8^{\text {th }}$ Piceeta s. lat. The $6^{\text {th }}$ vegetation tier is a community of Fageta s. lat., nevertheless its character with a regard to the occurrence of the main edificator, i.e. Picea abies, Abies alba and Fagus sylvatica is more similar to the higher vegetation tiers. The strong change of character of psocid taxocenoses (see above changes of characteristic species combinations) is clear in comparison with the $5^{\text {th }}$ and the $6^{\text {th }}$ vegetation tiers.

This work verifies the hypothesis that vegetation tiers and lower units of geobiocenological or foresttypological system have proved to be a suitable frame for zoocenological studies. These frames and units, as a characteristics of a potential state of ecosystems, together with the description of the tree species composition and the level of naturalness form a perfect base for studies focused on the animal taxocenoses structure.

This study confirmed that vegetation tiers are the main factor with the greatest influence on the variability of psocid taxocenoses. Vegetation tiers are an ideal frame for animal (entomological) studies. And finally, the order of psocids can be used for geobiocenological classification of ecosystems and also for evaluation of potential ecosystem changes.

\section{SUMMARY}

The aim of the paper is to summarize present proposals for forestry adaptation measures in a typical region affected by the decline of Norway spruce (the Slezské Beskydy Mts.) and to synthesize and confront them with literature sources. Under conditions of climatic changes it is possible to expect that similar episodes of decline will repeat in other regions. Forestry will have to respond to them by changes in management and measures mentioned above can be a starting point in fundamental principles for other similar regions.

In the Polish part of the Slezské Beskydy Mts., the decline of spruce stands began already at the beginning of the 90s. At the beginning of this century, its symptoms began to appear at the Jablunkov Forest District. This district is directly connected with this Polish region. Basic symptoms are as follows: yellowing, defoliation, decrease of radial increment and dieback of particular trees and groups of trees in stands of various ages, in some cases using final biotic mortality factors (Armillaria spp., Ips typographus, Ips duplicatus, Pityogenes chalcographus etc.), in other cases without identifiable mortality factors.

Basic forestry adaptation measures are generally summarized in Table I. Authors of this review assume that affecting the soil environment is too risk or even dangerous bringing only potential short-term benefits. It is evident that at lower vegetation zones it will not be possible to preserve the existing high proportion of Picea abies even in regions not affected by the spruce decline yet. The tree species composition should be modified in such a way the proportion of spruce to be minimized in the $4^{\text {th }}$ and $5^{\text {th }}$ vegetation tiers and the composition of tree species to be as rich as possible. The higher number of species creates conditions for the wider use of natural adaptation processes and thus for the generally higher resistance of forest stands. An increase in the proportion of Fagus sylvatica is problematic. In literature, a number of risks related to beech are mentioned, namely in situations of the elevated content of $\mathrm{CO}_{2}$ in the atmosphere and related to climatic changes. Present findings are, of course, often contradictory or with conditioned applicability. Generally, it is very complicated to predict summary effects on the health condition. The target proportion of beech should take into account risks mentioned above. On the other hand, it is evident that in case of the marked reduction of the proportion of spruce it will be rather complicated to avoid a certain increase (particularly from silvicultural aspects) in the proportion of beech in commercial forests.

Spruce stands aged over 60 years are more endangered by biotic pests and wind, their increment culminates earlier under conditions of chronic stress than it was calculated at the determination of 
the rotation period under present general instructions for management. With respect to these facts growing spruce under present rotation periods, which are about 90 to 110 years at medium locations, appears to be ineffective and considerably risk. Authors of this paper propose to reduce the rotation period in general directions of management by about 10 to 20 years and particularly a possibility of the operative reduction of rotation according to the stand condition up to 60 years.

\section{Acknowledgements}

This paper was worked up in the frame of the research project „Strategy of the management of territories with a special protection status" MSM 6215648902-04 of Faculty Forestry and Wood Technology of Mendel University of Agriculture and Forestry Brno.

\section{REFERENCES}

CULEK, M., (ed.), 1996: Biogeografické členění České republiky. Enigma, Praha: 347.

ELLENBERG, H., (ed.), 1973: Ökosystemforschung. Springer Verlag Berlin - Heidelberg - New York: 282. (sec. rec. In: MíCHAL, 1994).

ELLENBER, G H., 1978: Vegetation Mitteleuropas mit dem Alpen in ökologischer Sicht. Eugen Ulmer, Stuttgart: 943. (sec. rec. In: MÍCHAL, 1994).

GAUCH, H. G., jr., 1982: Nose reduction by eigenvector ordinations. Ecology, 63: 1643-1649.

GOWER, J. C., 1967: A comparsion of some methods of cluster analysis. Biometrics, 23: 623-637.

GÜNTHER, K. K., 1974: Die Tierwelt Deutschlands. 61. Teil. Staubläse, Psocoptera. VEB Gustav Fischer, Jena: 314.

HILL, M. O., 1974: Correspondence analysis - a neglected multivariate method. Applied Statistics, 23: 340-354.

HILL, M. O., GAUCH H. G., jr., 1980: Detrended correspondence analysis: an improved ordination technique. Vegetatio, 42: 47-58.

HOLUŠA, O., 200l: Příspěvek k poznání fauny pisivek (Insecta: Psocoptera) Př́rodní rezervace Smrk (Beskydský bioregion, Česká republika). Práce a Studie Muzea Beskyd, 11: 83-97.

HOLUŠA, O., 2003a: Vegetační stupňovitost a její bioindikace pomocí rádu pisivek (Insecta: Psocoptera). [Disertační práce]. Mendelova zemědělská a lesnická univerzita, Lesnická a dřevařská fakulta, Brno: 258.

HOLUŠA, O., 2003b: Fauna pisivek (Insecta: Psocoptera) Národní přírodní rezervace Mazák (Beskydský bioregion, Česká republika). Práce a Studie Muzea Beskyd (Př́rodní Vědy), 13: 83-98.

HOLUŠA, O., 2005: Fauna pisivek (Insecta: Psocoptera) Přírodní památky Kamenec v Podbeskydské pahorkatině (Podbeskydský bioregion, Česká republika). Práce a Studie Muzea Beskyd (Přírodní vědy), 15: 75-89.

HOLUŠA, O., 2007a: Fauna pisivek (Insecta: Psocoptera) vybraných lokalit Poodří (Pooderský bioregion, Česká republika). Práce a Studie Muzea Beskyd (Přírodní vědy), 19: 105-126.
HOLUŠA, O., 2007b: Příspěvek k poznání fauny pisivek (Insecta: Psocoptera) Přírodní rezervace v Podolánkách v Moravskoslezských Beskydech (Beskydský bioregion, Česká republika). Práce a Stud. Muz. Beskyd (Přir. védy), 19: 127-141.

HOLUŠA, O., 2007c: The influence of tree species composition to the composition of psocid taxocenoses (Insecta: Psocoptera) in the $7^{\text {th }}$ (= FagetiPiceeta s. lat.) and $8^{\text {th }}$ altitudinal vegetation zones (=Piceeta s. lat.) in the Moravskoslezské Beskydy Mts. Journal of Forest Science, 53, (Special Issue): 3-10.

HOLUŠA, O., 2009: Composition and diversity of psocid (Insecta: Psocoptera) taxocoenoses in forest ecosystems of the Abieti-fageta s. lat. zone in the Western Carpathian Mts. Journal of Forest Science, 55: 184-192.

HOLUŠA, O., HOLUŠA, J., st., 2008: Characteristics of $3^{\text {rd }}$ (Querci-fageta s. lat.) and $4^{\text {th }}$ (Fageta (abietis) s. lat.) vegetation tiers of north-eastern Moravia and Silesia (Czech Republic). Journal of Forest Science, 54: 439-451.

HOLUŠA, O., HOLUŠA, J., st., 2010: Characteristics of $5^{\text {th }}$ (Abieti-fageta s. lat.) and $6^{\text {th }}$ (Picei-fageta s. lat.) vegetation tiers of north-eastern Moravia and Silesia (Czech Republic). Acta Musei Beskydensis, 2: 49-62.

KAESLER, R. L., MULVANY, P. S., 1976a: Fortran IV program to compute diversity indices from information theory. Computer Geosciences, 2: 509-514.

KAESLER, R. L., MULVANY, P. S., 1976b: Fortran IV program to compute replicated diversity indices for random samples of specified size. Computer Geosciences, 2: 515-519.

LIENHARD, C., 1977: Die Psocopteren des Schweizerischen Nationalparks und seiner Umgebung (Insecta: Psocoptera). Ergebnisse der wissenschaftlichen Untersuchungen im Schweizerischen Nationalpark, band 14 (Nr. 75): 417-551.

LIENHARD, C., 1998: Psocoptéres Euroméditerranéens. Faune de France. Vol. 83. Fédération Francaise des Sociétes de Sciences naturelles, Paris, 517 pp. 
MíCHAL, I., 1994: Ekologická stabilita. 2. vyd. Veronica a Ministerstvo životního prostředí ČR, Brno, 275 pp.

MÜCKSTEIN, P., HOLUŠA, O., 2003: Composition of psocid taxocenoses (Insecta: Psocoptera) in dependence of level of naturalness of forest ecosystems in the Žd'árské vrchy hills. Journal of Forest Science, 49: 208-219.

ORLÓCI, R., 1975:Multivariate analysis in vegetation research. Dr. W. Junk Publishing, The Hague Boston, 451 pp.
POVOLNÝ, D., ZNOJIL, V., 1990: Vergleich zwischen Sarcophagini-Taxozönosen (Insecta, Diptera) Thürigens und der Tschechoslowakei. Rudolstädter Naturhistorische Schriften, 3: 43-61. PLÍVA, K., 1971: Typologický systém ÚHÚL. Ústav pro hospodářskou úpravu lesů Brandýs nad Labem, Brandýs nad Labem, 90 pp.

PLÍVA, K., 1991: Funkčně integrované lesní hospodářství. 1 - Přírodní podmínky v lesním plánování. Ústav pro hospodářskou úpravu lesů Brandýs nad Labem, Brandýs nad Labem, 263 pp. 
